\title{
MAKNA SIMBOLIK PAKAIAN ADAT (KABHANTAPI) PEREMPUAN PADA MASYARAKAT MUNA DI KECAMATAN KATOBU KABUPATEN MUNA
}

\section{${ }^{1 *)}$ Afnita Fitria Sara, ${ }^{2)}$ La Ode Dirman dan ${ }^{3)}$ Syahrun}

\author{
Program Studi Magister Kajian Budaya, Universitas Halu Oleo, Kendari \\ Jurusan Tradisi Lisan, Fakultas Ilmu Budaya, Universitas Halu Oleo, Kendari \\ Jurusan Tradisi Lisan, Fakultas Ilmu Budaya, Universitas Halu Oleo, Kendari
}

\author{
Corresponding Author: *Afnita Fitria Sara (afnitasitria.s1980@ gmail.com)
}

\begin{abstract}
Abstrak: Penelitian ini bertujuan untuk mendeskripsikan dan menganalisis makna simbolik pakaian adat (kabhantapi) perempuan pada masyarakat Muna di Kabupaten Muna, Kecamatan Katobu. Metode yang digunakan dalam penelitian ini adalah kualitatif dengan menggunakan teori semiotik oleh Charles Sanders Peirce.Informan dalam penelitian ini terdiri dari tokoh masyarakat Suku Muna, masyarakat yang memiliki pengetahuan tentang pakaian adat kabhantapi, dan pemerintah daerah.Pengumpulan data dilakukan dengan teknik observasi partisipan, wawancara mendalam, dan studi pustaka. Analisis data dilakukan dalam beberapa tahap; (a) tahap klasifikasi data, (b) reduksi data, (c) interpretasi data, dan (d) deskripsi data. Hasil penelitian ini menunjukkan bahwa pakaian adat (kabhantapi) perempuan pada masyarakat Muna memiliki banyak makna simbolik.Pakaian adat (kabhantapi) perempuanMuna digunakan sebagai simbol status wanita yang membedakan antara wanita yang telah menikah dan yang belum menikah. Pakaian adat (kabhantapi) perempuan Muna juga memiliki makna simbolik status sosial, bahkan bentuk, warna, dan motifnya memiliki makna simbolik yang unik atau spesifik.
\end{abstract}

Kata kunci: Makna simbolik, pakaian adat Kabhantapi, etnis Muna

Abstract: Thist study aims at describing and analyzing the symbolic meaning of Muna Women's Traditional Clothes (Kabhantapi) on Muna Ethnic Community at Muna regency, Katobu District. The method used in this study is qualitative and it used semiotic theory byCharles Sanders Peirce. The informants in this study consisted of Muna Ethnic community leaders, people who have knowledge of traditional Kabhantapi clothing, and the local government. Data collection was done by participant observation techniques, in-depth interviews, and literature study. Data analysis was carried out in several stages; (a) data classification stage, (b) data reduction, (c) data interpretation, and (d) data description. The result of this study shows that Muna women traditional clothes (kabhantapi) has much symbolic meaning. Muna women traditional clothes (kabhantapi) used as women status symbol which differs between women who have married and not yet one. Muna women traditional clothes (kabhantapi) also has social status symbolic meaning, and even its form, color, and motive have unique or specific symbolic meaning.

Keywords: symbolic meaning, Kabhantapi traditional clothes, Muna ethnic

\section{PENDAHULUAN}

Pakaian adat merupakan warisan budaya yang harus dijaga dan dilestraikan sebagai bentuk upaya pendokumentasian sejarah agar tidak mengalami pergeseran apalagi sampai 
punah dalam menghadapi tantangan jaman. Keberadaan pakaian adat dapat menyampaikan pesan-pesan mengenai nilai-nilai budaya yang pemahamannya dapat dilakukan melalui berbagai simbol yang tercermin dalam ragam hias pakaian adat tradisional.

Keberadaan pakaian adat sebagai warisan budaya masa lampau perlu adanya penanganan khusus karena pakaian adat merupakan hasil karya yang harus terus dijaga dan dilestarikan, agar tidak tergeser dengan adanya perkambangan jaman dan ganasnya arus globalosasi, walaupun saat ini pakaian tersebut sudah mengalami perubahan yang dipengaruhi oleh arus globalisasi.

Pakaian adat tradisional daerah merupakan salah satu unsur kebudayaan yang melekat di system organisasi sosial, karena beberapa pakaian adat merupakan penunjukan status sosial di dalam kehidupan masyarakat, salah satunya pakain adat masyarakat Muna yang disebut kabhantapi, tumbuh dan berkembang seiring dengan lahirnya masyarakat pendukung kebudayaan tersebut.

Keberadaan pakaian adat memiliki berbagai fungsi dalam kehidupan, baik itu fungsi ekonomi, sosial, politik, dan dan keagamaan, karena hal ini berkaitan dengan latar belakang lahirnya pakaian adat tradisional tersebut. Kemajuan teknologi dewasa ini seakan tidak memberi ruang kepada budaya lokal seperti pakaian adat untuk tampil eksis sehingga keberadaan pakaian adat tradisional sudah tidak nampak lagi, baik itu yang menggambarkan ciri khasnya maupun nilai-nilai budaya yang terkadnung didalamnya.

Salah satu budaya lokal yang tergeser akibat adanya perkembangan jaman dan ganasnya arus globalisasi adalah pakaian adat perempuan masyarakat Muna (kabhantapi).Bagi masyarakat Muna bahwa kabhantapi mempunyai makna tersendiri, yaitu merupakan spesifikasi tertentu baik, model, bentuk dan perhiasan yang digunakan sesuai dengan latar belakangstrata sosial dalam masyarakat Muna. Pakaian adat kabhantapi merupakan hasil kerajinan tenun masyarakat Muna. Kain tidak hanya berfungsi sebagai penutup tubuh belaka namun merupakan karya seni yang dipergunakan pada upacara-upacara adat didaerah masyarakat Muna. Pakaian adat tersebut mempunyai perhiasan yang bervariasi misalnya dalam pembuatan ornamen, pemakaian warna, penerapan motif, dan corak ragam hias yang menimbulkan kekaguman. Seiring dengan perkembangan jaman penggunaan pakaian adat perempuan etnik Muna (kabhantapi) hampir sebagian masyarakat sudah tidak mengetahui makna dan nilai yang terkandung dalam penggunaan pakaian adat tersebut. Sebagai contoh penggunaan pakaian adat tidak lagi berdasarkan strata sosial berdasarkan golongan masing-masing namun lebih kepada keinginan dari setiap pengguna atau individu yang menggunakan pakaian tersebut.

Berdasarkan latar belakang di atas, artikel ini yang bersumber dari hasil penelitian bertujuan untuk mengkaji dan menganalisis makna simbolis pakaian adat perempuan (kabhantapi) pada masyarakat Muna. Untuk mendeskripsikan makna simbolis pakaian adat perempuan (kabhantapi) pada masyarakat Muna tersebut diperlukan beberapa landasan berpikir secara teoretis, yakni teori semiotika yang dikembangkan oleh Charles Sander Peirce. Charles Sander Peirce ahli filsuf dari Amerika (1839-1914) mengutarakan bahwa kehidupan manusia dicirikan oleh pencampuran tanda dan cara 
penggunaannya dalam aktifitas yang bersifat representatif (Danesi 2010-33). Kata Semiotik berasal dari bahasa Yunani "semeion" atau tanda, diartikan sebagai ilmu tanda, Lambert, seorang ahli filsafat dari Jerman mempopulserkan istilah semiotika, pada abad ke 18 sebagai padanan kata dari logika. Peirce mengusulkan kata semiotik sebagai sebagai sinonim kata logika.Baginya logika harus mempelajari bagaimana orang bernalar. Penalaran itu, menurut teori Peirce yang mendasar, dilakukan melalui tanda-tanda.

Menariknya teori yang dikembangkan oleh Peirce, sehingga semakin banyaknya para ilmuan yang menggunakannya. Teori ini terus dikembangkan oleh Peirce, sehingga oleh Peirce, kembali menerangkan bahwa mengemukakan sebuah teori terhadap pemaknaan tanda yang disebut sebagai model triadic. Dalam model triadic, Peirce melihat tanda (representamen), sebagai bagian yang tidak terpisahkan dari objek referensinya serta pemahaman subjek atas tanda (interpretant) yang tidak terpisahkan" Sabour (2006: 12-13). Dengan begitu teori semiotik yang dikembangkan oleh Peirce tidak berakhir sampai disitu. Penjelasan berikutnya, Peirce menjelaskan hubungan dan atau benang merah dari penjelasan di atas. menghubungkan kaitan model triadic tentang teori semiotiknya yang terdiri atas representamen, objek dan interpretant.

Kabhantapi merupakan unsure kebudayaan kebudayaan yang ada pada masyarakat Suku Muna dalam hal menggunakan pakaian adat yang syarat dengan simbol-simbol. Dalam simbolsimbol tersebut sudah pasti memiliki makna yang terkandung di dalamnya yang diyakini oleh pemilik kebudayaan sangat menentukan arah dan hasil penggunaan pakaian adat yang mereka gunakan. Dari itu, maka kabhantapi harus diinterpretasikan dan diterjemahkan sehingga generasi muda sebagai pewaris dan penerus nilai-nilai budaya yang terkandung di dalamnya berkeinginan untuk memelikinya dan digunakan sebagai pedoman dalam kehidupan sehari-hari.Sejarah pakaian, dengan makna-makna simbolisnya, merupakan sejarah yang penuh pesona. Pakaian telah dikaitkan secara erat dengan jati diri (identitas, kepribadian) nasional, dengan struktur kelas, dengan kualifikasi professional, dengan konfersi masa tertentu, dengan tahap-tahap pertumbuhan dan penuaan, dengan pertunjukkan dan perayaan kesenian (Delistone : 2002).

Merujuk pada pada teori yang yang dikembangkan oleh Peirce.Sangat jelas dan cocok untuk mengungkap rumusan masalah dalam penelitian ini, yaitu mengkaji dan menganalisis makna simbolis penggunaan pakaian adat perempuan (kabhantapi) pada masyarakat Muna. Jika menarik hunbunga antara teori semiotik yang dikembangkan oleh Peirce terdiri atas 3 jenis tanda yaitu; ikon, indeks dan simbol, maka pada perempuan masyarakat Muna memenuhi tiga jenistanda tersebut, yang mana ketiganya telah include di dalam pakaian adat perempuan masyarakat Muna.

\section{METODE PENELITIAN}

Penelitian ini menggunakan metode kualitatif.Sugiono (1997:86); Muhadjir (1994:49); Ratna (2004:47), mengatakan bahwa pendekatan kualitatif merupakan suatu strategi penelitian yang menghasilkan keterangan atau data yang dapat mendeskripsikan realitas sosial dari berbagai peristiwa yang terkait dalam kehidupan masyarakat, sejarah, pelaku hubungan-hubungan kekerabatan, dan pergerakan-pergerakan sosial; maka sasaran utama dalam penelitian ini adalah menjelaskan atau mendeskripsikan tentang praktek penggunaan pakaian adat 


\section{kabhantapi. Dengan demikian,} penekanannya bukan pada pengukuran, tetapi lebih pada penjelasan yang bersifat holistik.

Informan dalam penelitian ini ditentukan berdasarkan teknik purposive sampling dengan pertimbangan; pertama, peneliti sudah menguasai kondisi di lokasi penelitian, kedua, permasalahan yang akan dibahas dalam penelitian ini bersifat mutlak, meskipun demikian peneliti tetap perlu menggunakan informan kunci.Jenis data dalam rencana penelitian ini adalah data kualitatif dan ditunjang dengan data-data pendukung lainnya.Data kualitatif diperoleh dari hasil obsevasi, wawancara, dan studi kepustakaan.Data yang digunakan adalah data tentang pakaian adat kabhantapi.

Teknik analisis data dalam penelitian ini dilakukan secara deskriptif-kualitatif dengan mengacu pada empat langkah yang dilakukan peneliti yaitu mengurutkan data ke dalam pola sesuai dengan permasalahan, mengelompokan data dalam kategori yang sesuai dengan interpretasi peneliti, sesuai dengan urutan data, dan sejalan dengan pemahaman yang akan diperoleh, serta penilaian atas data hingga memperoleh simpulan.

\section{HASIL DAN PEMBAHASAN}

Pembahasan ini mendeskripsikan makna simbolis pakaian adat (kabhantapi) perempuan pada masyarakat Muna. Makna simbolik pakaian adat (kabhantapi) perempuan dapat digunakan untuk membedakan perempuan yang sudah memiliki status pernikahan dengan yang belum menikah.

\section{Simbol Status Perempuan.}

Pakaian adat yang digunakan oleh perempuan Muna memiliki perbedaan antara yang sudah menikah dengan yang belum menikah. Perbedaan penggunaan pakaian yang berbeda yang diterapkan oleh perempuan Muna merupakan bentuk isyarat kepada anggota masyarakat yang lain., utamanya dari kalangan laki-laki. Berikut ini akan dipaparkan mengenai makna penggunaan pakaian yang berbeda antara perempuan yang sudah menikah dengan yang belum menikah.

1. Perempuan Sudah Menikah

Pada masyarakat etnik muna, juga memiliki cara berpakaian tersendiri bahkan memiliki sebutan lain sebagaimana ungkapan salah satu tokoh masyarakatnya yang beranama La Giy mengatakan bahwa :

"Karena ada bahasanya kabhantapi itu dua lapis sarungnya. Orang muna bilang ra tapi betano.Ra tapi betano itu adalah orang yang sudah bersuami". (Hasil wawancara 15 Desember 2017)

Disini dapat digambarkan bahwa makna simbol penggunaan kabanthapi yang menggunakan dua lapis sarung adalah para wanita yang telah bersuami.Makna simbolis "dua" berarti adanya dua entitas, yaitu suami dan istri. Seperti yang dituturkan oleh Wa Hamnia:

"Kalau dulu, pakaian saja.Namanya orang kabhantapi itu, berarti dia sudah orang tua to?Sudah menikah, sudah berkeluarga.Namanya sudah berkeluarga pasti dia banthapi.Kalau dulu itu namnaya sudah menikah, jadi pakai Kabhantapi, dua lapis sarungnya.Dua lapiskan berarti sudah berlapis, sudah punya suami, begitu maksudnya".(Hasil wawancara 5 Januari 2018)

Dari keterangan tersebut dapat ditarik satu gari benang merahnya, yang menearangkan bahwa kabhantapi itu berupakan pakaian perempuan etnik Muna yang telah menikah.Sehingga dengan demikian kita dapat membedakan antara perempuan yang telah menikah atau berumah tangga dengan perempuan yang masih sendiri atau belum menikah dalam hal ini belum berkeluarga. 
Penjelasan dari catatan Couvreur (1935), kedua kain wanita yang telah bersuami dililit bersama diatas dada lalu disimpul. Dari cara memakai kedua kain itu, kelihatan golongan wanita yang telah menikah itu. Makna simbolisnya adalah bilamana kain dililit bersama diatas dada lalu disimpul maka ini menandakan status perempuan yang telah bersuami. Selanjutnya Couvreur (1935) menjelaskan bahawa jika seorang wanita yang telah menikah dengan suami yang tidak memiliki jabatan, lalu datang berkunjung ke rumah seorang mino (kepala kampung (dari golongan Walaka) ataukino (kepala kampung dari golongan Kaomu), maka sarung yang ketiga itu dipakai di pinggang oleh seorang golongan Каоти dengan cara yang sama seperti seorang laki-laki Каоти. Disini dapat ditarik kesimpulan bahwa makna simbolis penggunaan sarung ketiga yang dipakai di pinggang adalah bahwa perempuan ini memiliki suami yang tidak memiliki jabatan pada saat dia berkunjung ke rumah seorang mino (kepala kampung (dari golongan Walaka) atau kino (kepala kampung dari golongan Kaomu).

Begitu pula bagi perempuan yang telah menikah dari kaum Anangkolaki. Couvreur (1935) mencatat bahwa bilamana wanita dari golongan Anagkolaki mendatangi rumah seseorang yang lebih tinggi status sosialnya, maka mereka juga mengenakan tiga helai kain.Kain yang ketiga dipakai terikat ketat di bagian pinggang di atas kain-kain lainnya.Cara ini mirip dengan penggunaan bhida (kain ikat pinggang) oleh laki-laki. Aturan ini juga berlaku bagi para janda dan wanita yang telah bercerai. Disini dapat digambarkan bahwa makna simbolis dari kain yang ketiga yang dipakai terikat ketat di bagian pinggang di atas kain-kain lainnya dalah bahwa perempuan ini berasal dari kaum Anagkolaki yang sedang berkunjung ke rumah kaum yang lebih tinggi status sosialnya.

2. Perempuan Belum Menikah

Untuk perempuan yang belum menikah biasanya hanya mengenakan selembar sarung atau kain (Couvreur : 1935). Intinya, perempuan yang belum bersuami, dalam keadaan apapun harus selalu mengenakan satu helai kain.Begitu pula jika mereka datang berkunjung ke rumah seseorang yang lebih tinggi status sosialnya. Mengenakan kain dengan cara mengikat pada salah satu bahu, bukanlahmenurut adat; begitu pula dengan cara menarik kain itu dari muka sampai di leher lalu mengikatnya di belakang. Kedua cara ini banyak dilakukan oleh para wanita yang belum menikah, pertama-tama karena suka berlagak, sebab mereka tahu bahwa mengenakan kain dengan cara ini lebih bagus dan yang kedua untuk mengurangi rasa malu dengan menutupi bagian dada kalau berhadapan dengan kaum lelaki.

Lebih tegasnya Couvreur (1935) mencatat bahwa menurut adat masyarakat Muna, sehelai baju boleh dipakai oleh kaum wanita, baik untuk wanita yang sudah menikah maupun yang belum.Warna baju ini dipilih menurut selera mereka.Dalam hal ini, baju tertutup seluruhnya dengan hanya belahan kecil sebagai lubang kepala.Baju ini terdiri dari satu potong kain.Panjangnya kurang lebih sampai di pinggang atau lebih sedikit.Wanita yang belum bersuami mengenakan baju yang diatasnya kain (kain itu diikat di atas dada).

\section{Makna Simbolis Pakaian Adat (Khabantapi) Perempuan Berdasarkan Status Sosial}

Menurut Soerjono Sekanto (Samhis Settiawan, 2016) stratifikasi sosial adalah perbedaan penduduk atau masyarakat kedalam kelas-kelas secara bertigkat. Pitirin A. Sorokin (Samhis Seiawan, 2016) menjelaskan stratifikasi 
sosial adalah perbedaan penduduk atau masyarakat kedalam kela-kelas secara bertingkat hierarkis. Perwujudannya ialah adanya lapisan-lapisan didalam masyarakat, setiap lapisan itu disebut dengan strata sosial. Lebih lanjut Sorokin mengatakan bahwa stratifikasi sosial merupakan ciri yang tetap pada setiap kelompok sosial yang teratur. Lapisanlapisan ini dalam masyarakat memang idak jelas batas-batasnya, tetapi tampak bahwa setiap lapisan akan terdiri atas individu-individu yang mepunyai tingkatan atau strata sosial yang secara relatif adalah sama. Kedudukan atau starata sosial dalam suatu masyarakat merupakan faktor bawaan dari jaman kerajaan.Perbedaan strata soaial seperti halnya anggota tubuh yang terdiri dari bebrapa bagian seperti kepala dan anggota tubuh yang lainnya.

Berikut ini dijelaskan makna simbol dari masing masing strata sosial masyarakat Muna yang dikaitkan dengan penggunaan pakaian adat kabhantapi.

\section{Makna Simbol Pakaian Adat} Kabhantapi Pada Golongan Kaomu

Kaum perempuan kaomu mengenakan satu lembar kain sebatas mata kaki, kain kedua diletakkan di atasnya, tetapi cuma ditempatkan sedikit di atas lutut. Wanita dari golongan kaomu dan saramengenakan baju dari sutra, laken (kain sekelat) atau kain pembuat kopiah. Menurut La Bua:

"penggunaan kain sutra mengandung makna simbol bahwa perempuan dari kaum kaomu memperlihatkan sikap yang lemah lembut atau penuh kelembutan seperti yang terdapat pada kain sutra yang memang berbahan lembut". (Hasil wawancara tanggal 9 Nopember 2019).

Berdasarkan

penjelasan wawancara di atas, makna simbol lainnya mengandung arti keanggunan dan keluhuran. Dikatakan keanggunan dan keluhuran karena kain sutra termasuk jenis kain yang cukup bernilai tinggi dibanding jenis kain lainnya.Oleh karenanya, jenis kain ini biasanya hanya dimiliki oleh orang-orang dari status sosial yang tinggi.

Selain itu, pada golongan Kaomu juga memiliki cirri khas dengan melihat berdasarklan pada warna Kabhantapi yang digunakan. Hal tersebut di utarakan oleh salah satu informa perempuan bernama Wa Abe, mengatakan:

"pakaian perempuan Muna untuk golongan Каоти warna kuning dan bawahnya warna putih. Warna putih ini sebagai simbol kesucian ".(Hasil wawancara Jum'at, 8 desember 2017).

Penjelasan tersebut, bahwa pada perempuan Kaomu mengenakan Kabhantapi dengan perpaduan warna kuning dan warputih. Sehingga dengan demikian dengan melihat corrak warna yang dikenakan saja sudah memberitahukan dari golongan perempuan itu berasal dan statusnya pun semakin jelas.

\section{Makna Simbol Pakaian Adat Kabhantapi Pada Golongan Walaka \\ Couvreur (1935) menjelaskan} bahwa wanita dari golongan saradan juga kaomu diperbolehkan memakai sejumlah kancing emas yang kecil dalam satu rangkaian di atas pembuka lehernya.Jumlah kancing paling banyak enam buah. Menurut La Bua, makna simbolik jumlah kancing emas bagi perempuan kaum sara, yaitu:

"bila jumlah kancing ada empat buah, ini melambangkan jumlah sahabat Rasulullah. Bila jumlah kancing ada lima buah hal ini melambangkan rukun islam. Bila jumlah kancing ada enam hal ini melambangkan jumlah rukum iman. Sedangkan emas itu sendiri merupakan simbolisasi dari 
warna matahari serta merupakan cahaya untuk menerangi kegelapan".

(hasil wawancara, 6 Januari 2018)

Keterangan di atas mengandung arti bahwa, jumlah kancing yang digunakan bukan hanya sekedar direkatkan saja.Tetapi dari segi agama bahwa perempuan etnik Muna, sangat dekat dengan agama yang dianutnya yaitu Islam. Mulai dari penggunaan jumlah kacing baju sebesar empat buah, lima buah sampai pada enam buah. Ke tiga jumlah kancing baju tersebut masingmasing memiliki makna.Sebegaiamana penjelasan di atas tadi. Bahwa kancing empat menggambarkan jumlah sahabat Nabi Rasullullah, S.W.T, kancing lima menggambarkan rukun islam dan kancing Enam menggambarkan rukun iman, yang diajarkan ketiga jumlah kancing tersebut sekaligus menjadi salah satu pedoman dalam menjalankan ibadah. Sedangkan filosofi lainnya bahwa perempuan kaum saradikiaskan memberikan cahaya yang terang bagi kaum lainnya. Hal ini tentu saja tetap berpegang pada agama islam sebagai penjelasan sebelumnya. Lebih lanjut La Bua menjelaskan bahwa:

Sekarang itu, banyakmi yang sudah tidak mengerti tentang artinya dari jumlah kancing dengan kancing emas dari pakaian perempuan di Muna.

(Hasil wawancara tanggal 6 Januari 2018).

Maksud dari wawancara di atas, dapat diketahui pemahaman masayarakat saat ini semakin berkurang pengetahunnya terkait dengan makna pakain adat perempuan Muna (kabhantapi). Belum lagi penjelasan dari arti jumlah kacing baju termasuk warna emas yang di gunakan pada kancing baju tersebut. Warna emas kancing baju yang di gunakan berkaitan erat dengan filosofi makrifat dalam Islam.
3. Makna Simbol Pakaian Adat Kabhantapi Pada Golongan Anagkolaki

Couvreur (1935) menerangkan bahwa perempuan dari golongan Anagkolakimengenakan baju dengan cara yang sama, namun mereka memiliki tanda pengenal, yaitu garis sempit dengan warna berbeda pada daerah pinggir leher dan bagian bawah lengan. Pakaian untuk budak wanita sama seperti yang ditetapkan untuk Anangkolaki poinokontu lakonosau. Menurut keterangan La Bua, "motif garis sempit mengandung makna simbolik yang mengacu pada keterbatasan hak-hak sosial yang dimiliki oleh kaum Anagkolaki". (Hasil wawancara tanggal 9 Nopember 2019).

Hal ini juga tentu dengan mengingat posisi status sosial mereka yang masuk golongan ke tiga dari lima golongan masyarakat Muna menurut, (Couvreur 1935).

\section{Makna Simbolis Bentuk, Warna dan Motif Pakaian Adat (Kabhantapi) Perempuan pada Masyarakat Muna}

Berikut ini dijelaskan berbagai makna simbolik bentuk, warna dan motif pakaian adat Kabhantapi.

1. Makna Simbol Bentuk

Dalam konteks simbol bentuk dari pakaian adat Kabhantapi, yang paling menonjol adalah jumlah kain yang melapisi Kabhantapi.Bahwa kaum wanita yang telah bersuami mengenakan dua lembar sarung, sedangkan yang belum menikah memakai hanya satu lembar.

Hal ini memiliki makna simbolik bahwa sehelai kain melambangkan satu entitas, yaitu seorang wanita yang belum menikah, sedangkan dua helai kain melambangkan adanya dua entitas, yaitu suami dan istri. Disisi lain, penggunaan tiga helai kain melambangkan adanya kaum dengan status sosial yang lebih rendah dan berkunjung ke rumah kaum yang lebih tinggi status sosialnya. Selain hal itu, kabhantapi juga menjadi salah 
satu terhadap kaum laki laki masyarakat Muna untuk tidak mengganggu perempuan Muna yang telah mengenakan pakaian kabhantapi karena perempuan tersebut secara simbolis telah berkeluarga. Dengan begitu laki-laki Muna dapat menjaga sikapnya dengan bersompan santun yang baik terhadap perempuan Muna yang telah mengenakan kabhantapi. Hal tersebut sejalan dengan perkataan salah satu tokoh adat masyarakat Muna, bapak La Giy yang mengakatan "kapan dia sudah bhantapi berarti sudah berkeluarga, ini juga sebagai isyarat untuk laki-laki bahwa jangan berani lagi laki-laki mengganggu, karena itu berarti dia sudah berkeluarga, Hasil wawancara Senin, 13 November 2017'.

Di sisi lain, golongan kaomu, yaitu wanita dari strata sosial tertinggi, mengenakan satu lembar kain sebatas mata kaki, kain kedua diletakkan di atasnya, tetapi hanya sedikit di atas lutut. Penggunaan kain sebatas mata kaki mengandung makna simbol yang merujuk kepada kaum kaomu. Pada wanita dari golongan walaka, kain yang kedua cuma sebatas betis. Kain sebatas betis ini mengandung makna simbol yang merujuk kepada kaum walaka. Artinya, posisi kain sebatas mata kaki dan posisi kain sebatas betis keduanya sarat dengan makna simbol bentuk yang jelas menunjukkan identitas dari kaum yang berbeda strata sosial, yaitu kaomu dan walaka.Wanita dari golongan anangkolaki (kelompok tertinggi dari kaum anagkolaki) mengenakan kain kedua sedikit lebih panjang dari wanita kaum Walaka, yaitu melewati batas betis. Disisi lain, wanita dari golongan anagkolaki mengenakan kedua kain sebatas mata kaki di mana kain atasnya tergantung beberapa centimeter lebih pendek dari kain di bawahnya. Jadi, akan terlihat bagian pinggiran yang sempit dari kain bawah. Kain yang melewati batas betis dan kain sebatas mata kaki di mana kain atasnya tergantung beberapa centimeter lebih pendek dari kain di bawahnya memiliki makna simbol bentuk yang merujuk kepada eksistensi kaum Anagkolaki atau golongan yang ke tiga dalam sistem stratifikasi sosial masyarakat Muna.

2. Makna Simbol Warna

Makna simbol warna dalam pakaian adat Kabhantapi juga penuh dengan makna filosofis yang sangat mendalam. Menurut keterangan La Bua, warna pakaian Kabhantapi juga penuh dengan makna simbol yang sangat kental. Dari hasil wawancara dengan La Bua, diperoleh keterangan bahwa:

"warna merah, yang merupakan salah satu warna yang cukup dominan dalam pakaian adat Kabhantapi, mengamdung makna simbol keberanian dan sikap ksatria. Warna merah juga melambangkan kekuatan, perjuangan, perhatian, simbol api, cinta, ketenaran, dan sumber energi. Warna hijau mengandung makna simbol keterbukaan. Warna hitam mengandung makna simbol keabadian. Warna putih mengandung arti menjaga kesucian dan kebersihan. Putih juga melambangkan kedamaian, kesederhanaan, spiritualitas, permohonan maaf, bebas dari kesalahan, dan persatuan. Warna dasar pakaian Kabhantapi adalah putih. Warna biru mengandung makna simbol kedewasaan.Biru juga mengandung arti kasih sayang, kelembutan, kesetiaan, panutan, kepercayaan diri, idealisme, kecerdasan dan persahabatan. Warna kuning mengandung arti keagungan. Kuning dapat pula disimbolkan sebagai kebahagiaan, kebijaksanaan, pemahaman, imajinasi logis, kegembiraan, kerjasama, optimisme, harapan, serta energi sosial." (Hasil wawancara tanggal 9 Nopember 2019). 
Warna merah mengandung sangat banyak arti. Mulai dari keberanian dan sikap ksatria, termasuk kekuatan, perjuangan, perhatian, simbol api, cinta, ketenaran, dan sumber energi. Kelengkapan arti warna merah, sekaligus menggabarkan sikap dan perwatakan pada perempuan etnik Muna. Hal ini meberikan juga bahwa gambaran wanita etnik Muna yang begitu mandiri dalam hidupnya.

$$
\text { Warna hijau merupakan }
$$
representasi warna bumi.Hijau dapat pula berarti pertumbuhan, kesuburan, persabatan, keseimbangan, penyembuhan fisik, daya tahan, keajaiban dan kelimpahan. Warna hitam melambangkan perasaan yang sangat mendalam, harga diri, kekayaan, kemapanan, kekuatan, dan misteri. Dengan mengenakan pakaian warna hitam, dikiaskan bahwa perempuan Muna memiliki perasaan yang sangat mendalam, namun sangat menjunjung tinggi harga diri, yang semuanya akan menuju keabadian. Warna putih mengandung makna bahwa perempuan Muna selalu menjaga kesucian, yang mengandung arti selalu menjaga kehormatannya sebagai seorang wanita, dan selalu penuh kedamaian serta kesederhanaam dengan tetap menjaga persatuan walaupun terbagi menjadi 5 golongan ataupun berada di perantauan. Warna biru mengandung makna simbol kedewasaan. Biru juga mengandung arti kasih sayang, kelembutan, kesetiaan, panutan, kepercayaan diri, idealisme, kecerdasan dan persahabatan. Bila warna biru dipadukan dengan kuning dan merah, maka akan menunjukkan makna simbol kepercayaan dan kesehatan. Warna kuning mengandung arti keagungan. Kuning dapat pula disimbolkan sebagai kebahagiaan, kebijaksanaan, pemahaman, imajinasi logis, kegembiraan, kerjasama, optimisme, harapan, serta energi sosial.
Kuning yang merepresentasi warna matahari memiliki kandungan makna simbol yang sangat mendalam.

Berdasarkan penjelasan makna simbol warna di atas dapat ditarik kesimpulan bahwa pemilihan warna pakaian adat Kabhantapi sebenarnya tidak asal memilih warna karena ternyata warna yang digunakan pada pakaian adat ini memiliki makna simbol masingmasing yang kebanyakan tidak diketahui orang banyak. Penjelasan mulai dari warna merah, hijau, hitam, putih, biru dan kuning kesemua simbol warna tersebut, masing masing mememiliki arti yang berbeda. Namun merupakan kombinasi simbol warna yang saling menlengkapi satu sama lainnya.

\section{Makna Simbol Motif}

Pakaian adat Kabhantapi juga tidak lepas dari motif atau corak.Yang paling umum terlihat adalah motif garis dan motif kotak-kotak. Untuk motif garis, kebanyakan hanya ada 2 macam, yaitu garis horisontal dan garis vertikal. Garis horisotal adalah garis lurus yang membentang dari arah kiri ke kanan ataupun sebaliknya. Menurut keterangan La Bua, tipe garis ini mengandung makna simbol ketenangan, relaksasi, diam dan statis, serta siap membuka diri terhadap hal-hal yang bersifat positif dan rela berbagi kebahagiaan dengan orang lain.

Di sisi lain, ada pula tipe garis vertikal. Garis vertikal adalah garis yang membentang dari atas kebawah atau sebaliknya.Menurut keterangan La Bua, tipe garis ini mengandung makna simbol kekuatan, stabilitas serta kemegahan. Namun, lebih lanjut La Bua mengatakan bahwa bahwa sebenarnya makna yang paling dalam dari simbol garis vertikal adalah yang tua menyayangi yang muda, yang muda menghormati yang tua, suami menyayangi dan melindungi istrinya, istri selalu setia, taat dan menjaga kehormatan suami, pemimpin mengayomi dan 
melindungi rakyatnya, dan rakyat patuh kepada pemimpinnya.

Motif yang juga banyak digunakan pada pakauan adat Kabhantapi adalah motif kotak-kotak. Makna simbol motif kotak-kotak yang terdapat pada pakaian adat perempuan Muna memiliki makna religius yang sangat mendalam. Menurut La Bua:

"Maksud dari kotak-kotak pada pakaian adat Kabhantapi mengandung arti di manapun perempuan Muna pergi, selalu berada dalam garis adat istiadat". (Hasil wawancara tanggal 10 Nopember 2019)

Artinya bahwa mereka senantiasa memegang teguh adat istiadat yang tidak bertentangan dengan Agama, dalam hal ini Agama Islam.Mereka mau pergi kearah timur, kearah barat, utara, maupun selatan, hati mereka tetap lurus dan tidak mudah tergoda dengan hal-hal yang dilarang oleh agama dan hukum adat.

\section{KESIMPULAN}

Berdasarkan hasil penelitian tentang makna simbolik penggunaan pakaian adat perempuan (kabhantapi) pada masyarakat etnik Muna maka dapat disimpulkan sebagai berikut. Makna simbolis pakaian adat perempuan (kabhantapi) pada masyarakat etnik Muna, yaitu: 1) bahwa pakaian adat Kabhantapi menjadi pembeda bagi Perempuan yang belum menikah dengan yang sudah menikah. Pada perempuan yang belum menikah biasanya menggunakan selembar kain sarung saja, sedangkan perempuan yang sudah menikah biasanya menggunakan lembar kain sarung secara berlapis. 2) Pakaian adat kabhantapi juga memiliki makna simbol status sosial. Dengan begitu dapat terlihat jelas perempuan tersebut apakah berasal dari kaum golongan kaomu, sara ataukah anangkolaki. Yang terakhir adalah makna simbol dari bentuk, warna dan motif pakaian adat Kabhantapi yang memiliki makna simbol yang sangat khas. 3) Pada pakaian adat kabhantapi terdapat juga bagian-bagian yang perlu diperhatikan, yaitu pembagian pakaian adat kabhantapi dapat dilihat dari bentuk leher baju adatnya, bentuk sarung lapisan ke dua bagian terluar, dan juga penggunaan selendang serta posisi tinggi rendahnya sarung, pada masing-masing kaum golongan. Pada kaum golongan kaoumu baju adat yang digunakan itu berleher bundar, lapisan sarung ke dua yang paling luar ujung sarungnya dibiarkan jatuh terlipat ke depan dan posisi sarungnya berada di atas lutut. Sedangkan untuk kaum golongan sara, baju adatnya itu pada bagian lehernya dibuat berkera, ujung sarung pada bagian lapisan sarung ke dua terluar dibiarkan muncul di atas.

\section{DAFTAR PUSTAKA}

Covreur, j. 1935.Dalam Bahasa Belanda. Diterjemahkan oleh Rene van den Berg. 2001. Sejarah dan Kebudayaan Kerajaan Muna. Kupang: Artha Wacana Press.

Danesi, Marcel. 2010. Pesan, Tanda, dan Makna: Buku Teks Dasar Mengenai Semiotika dan Teori Komunikasi. Yogyakarta: Jalasutra.

Dillistone, F.N.2002. The Power of Symbols. Penerjemah A.Widyamartaya.

Hoed, B.H. 2002.Strukturalisme, Pragmatik, dan Semiotika Dalam Kajian Buadaya. Jakarta: Wedatama Wisdaya Sastra.

Muhadjir, N. 1992.Metodologi Penelitian Kualitatif Telaah Positivistik, 
Copyright (C) 2020 Jurnal Fokus Penelitian Budaya : Masalah-Masalah Kebudayaan dan Masyarakat.

Kajian Budaya Pascasarjana Universitas Halu Oleo Kendari Sulawesi Tenggara, e-ISSN: 2502-3268. Open Access at: ttp://ojs.uho.ac.id/index.php/JPeB

Rasionalistik, Fenomenologik Realisme Metaphisik. Yogyakarta: Rakesarasin.

Ratna, I. N.K, 2004. Teori, Metode dan Teknik Penelitian Sastra dari Struktutalisme Hingga

Posttrukturalisme Prespektif Wacana Naratif. Yogyakarta: Pustaka Pelajar.

Sabour, A. 2006.Semiotika Komunikasi. Bandung: Remadja Rosda Karja.

Sachari, A. 2006. Metodologi Penelitian Budaya Rupa: Desain, Arsitektur Seni Rupa, dan Kriya. Jakarta: Erlangga

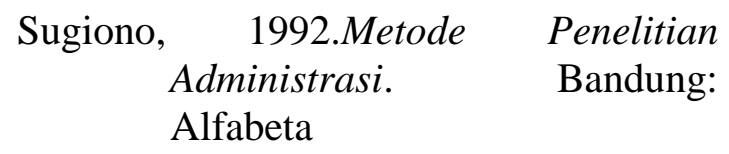

